\title{
DYSPEPTIC AMOURS, PETTY ADHESIVENESS, AND WHITMAN'S IDEAL OF PERSONAL RELATIONS
}

\section{Carmine SARracino}

When Humpty Dumpty DEFINES "GLORY" as a nice knock-down argument, Alice understandably objects. Humpty Dumpty, however, is unyielding. To him the whole matter of meaning simply comes down to this: either we bully words into meaning what we want them to mean, or they bully us.

With language as in life, Walt Whitman was no bully. Whether by sleight of hand or by charm, then, like Humpty Dumpty he often made words mean what he wanted them to mean, common usage and dictionaries notwithstanding. Examples abound. "Chuff," for instance, commonly meant a cheek swollen with fat. Whitman, however, made the word mean the fleshy part of the hand. The Spanish word camarada, a roommate merely, became for Whitman "camerado," the most steadfast friend. If he could not redefine an English word, or borrow, usually with some alterations, from Spanish, French, Greek or even Sanskrit, he simply made up an altogether new word. ${ }^{1}$ As Whitman's readers, then, we cannot always elucidate a text simply by consulting a nineteenth century dictionary, or even by researching presumed influences, such as phrenology, from whose vocabulary of character traits he is known to have drawn extensively. Whitman's usage is, while not so eccentric as Humpty Dumpty's, certainly idiosyncratic.

The words "amorous" and "amative" furnish good examples. Whitman at times uses the words as virtual epithets, and often modifies them pejoratively, for instance with the word "mere." But even if we look to phrenology, the nineteenth century pseudoscience, we find that to Fowler and Wells (the phrenologists whom Whitman read, and whom he consulted in 1849) "amativeness" and "amorousness" were healthy traits and suggested weakness of moral character only when in excess. ${ }^{2}$ To understand Whitman's usage of "amorousness" and "amativeness" we must understand the meanings with which Whitman the social reformer and mystic invested these words. I will argue later that we must do the same with "adhesiveness," the ideal of male-male relations. Both as reformer and as mystic, Whitman had clear purposes that his words, whatever their conventional meanings, had to serve. 
For Whitman, a friend and supporter of Eliza Farnam, Abby Price and other feminists of the day, "amorousness" and "amativeness" were at the core of conventional romance, which itself comprised the main obstacle blocking the entrance of women into the social spheres of business, politics and suffrage. In Democratic Vistas we find Whitman's well-known denunciation of dandies "forever occupied in dyspeptic amours with dyspeptic women." 3 The vehemence of Whitman's feelings on this matter is clear at least as early as his 1856 public letter to Emerson, in which he says, "This tepid wash, this diluted deferential love, as in songs, fictions, and so forth, is enough to make a man vomit. ...", Amours, then (the same root of course as "amorous" and "amative"), are "dyspeptic"-born of unhealthy digestion, not so much affairs of the heart as of the bowels. (I will later return to this aspect of health.) But Whitman's sarcastic observation was no mere disapproval of contemporary manners; it was a socially and humanly crucial criticism: "To the movement for the eligibility and entrance of women amid new spheres of business, politics, and the suffrage, the current prurient, conventional treatment of sex is the main formidable obstacle" (PW, 2:494, italics mine).

The "current prurient treatment of sex" manifested itself in promiscuity and in prudery, which Whitman saw as not polar or even distinct, but rather as two expressions of the same derangement. In "The Good Gray Poet," W.D. O'Connor defined "squeamishness" as "the Siamese twin-brother of indelicacy," a connection Whitman himself makes when he quotes from a paper by P.H. Rathbone of Liverpool on "The Undraped Figure in Art:" "The Turk regarded and regards women as animals without soul, toys to be played with or broken at pleasure, and to be hidden, partly from shame, but chiefly for the purpose of stimulating exhausted passion" ( $P W, 2: 495)$.

All Whitman's work stands as an argument, to put it that way, against shame. But to argue so is not necessarily to endorse sexual looseness, an inferential mistake no doubt committed by the New England Free Love League when they officially adopted Leaves of Grass in 1883, but also common among new Whitman readers, and even found among critics. Bucke, in words so extensively edited and revised by Whitman that we might more accurately identify the author as Bucke-Whitman, anticipated such an error: "Sexual shame as an inherent rule or concept in the normal mind, being abolished (as it must eventually be), it does not follow that the sexual organs, acts and feelings should be paraded or unveiled." ${ }^{\prime 6}$ Nelly O'Connor remembered that in their Sunday evening discussion club, a standard topic was free-love, and Whitman was its fiercest denouncer: "He gave it no quarter, said that its chief exponent and disciple-Stephen Pearl Andrews - was a type of Mephistopheles, a man of intellect without 
heart, and there were no terms too strong in which to express his opinion of its 'damnable' teachings and practices" (Champion, 52). So serious was Whitman's belief in chastity and fidelity that Jerome Loving, among others, speculates that the falling out between Whitman and W.D. O'Connor may in fact have been precipitated by O'Connor's extramarital affairs, rather than by disagreements over abolition, serious as those were (See Champion, 100-102).

Whitman's particular use of the terms "amorous" and "amative" are further informed by the other role I have mentioned, Whitman as mystic. Whitman's mysticism will be especially important when I turn later to "adhesiveness," so let me here offer a model of consciousness which I believe sheds light on Whitman's mysticism, and thereby on these important terms as well. In June of 1853 or 1854 (the notebooks are not clear) Whitman apparently underwent a transforming "mystical experience" which he described poetically in 1855 in "Song of Myself" (in what later became Section 5 of that poem) and then further described and elaborated throughout his writings as late as "To the Sunset Breeze" in 1890, two years before his death. Generalizing from many separate experiences, Whitman wrote of this unique state of consciousness in Democratic Vistas:

There is in sanest hours a consciousness, a thought that rises, independent, lifted out from all else, calm, like the stars, shining eternal. This is the thought of identityyours for you, whoever you are, as mine for me. Miracle of miracles, beyond statement, most spiritual and vaguest of earth's dreams, yet hardest basic fact, and only entrance to all facts. In such devout hours, in the midst of the significant wonders of heaven and earth (significant only because of the $\mathrm{Me}$ in the center), creeds, conventions, fall away and become of no account before this simple idea. Under the luminousness of real vision, it alone takes possession, takes value. Like the shadowy dwarf in the fable, once liberated and look'd upon, it expands over the whole earth, and spreads to the roof of heaven. $(P W, 2: 394)^{7}$

Whitman had discovered what in Vedic literature, whose main topic is the nature of consciousness, is referred to as the fourth state, turiya, transcendental consciousness. Whereas all other states of consciousness (walking, sleeping, dreaming) are fragmented, bounded by an object of perception, transcendental consciousness is unified and limitless, like a "shadowy dwarf" that is liberated and spreads limitlessly in every direction. Transcending all objects of awareness, transcending ego, one becomes aware of the ground of all perception, thought, emotion-pure consciousness itself. Whitman uses several terms (the "mere fact consciousness," "interior consciousness," "Self") to identify the self-referential experience of consciousness itself, distinguishing it from the ordinary experience of objects of consciousness (thoughts, perceptions, sensations, emotions). Whitman had, then, not merely experienced some unusual "thing" as the content of his con- 
sciousness, but, more profoundly, he had experienced a restructuring of the very process of experience itself.

Normally (using a model of consciousness derived from Vedic literature), the process of experience consists of three components: the knower, the process of knowing, and the object of knowledge. " ${ }^{8}$ "I am tasting an apple," according to this linear model of consciousness, can be represented: I (knower) experiencing (process) apple (object). Whitman, however, found his way to an experience rare in the West, but quite well known in the ancient literatures of the East, in which the three components are merged into singularity.

Vedic literature (especially the Upanishads) prescribes meditation as a technique to gain this experience in a systematic way. In meditation, a mantra, or sound, is the object of awareness. Gradually, however, the object becomes more and more refined until it disappears altogether. At that point a curious thing will have happened: If the knower continues to be conscious, but there is no longer an object of consciousness, of what will the knower be conscious? The knower becomes conscious of himself in the act of being conscious - becomes conscious, as Whitman put it, of "the mere fact consciousness." We could describe what happens in several ways. We could say that the knower is, then, himself the object of consciousness. Or we could say that the process of knowing is the object. To say it that way would then make the knower identical with the process of knowing. And in fact it does not matter how we say it because the three separate components of knowing-knower, process, and object, have merged (a favorite Whitman word) into a transcendent, circular unity. Whitman's "I celebrate myself," for example, merges these separate components: the "object" becomes the "subject," but the subject is the "process," the celebrating-like Yeats's dancer who is the dance, and also the dancing. Distinction, separation, is impossible, simply disallowed by a unique state of consciousness. Rather than fragmented linearity, a broken world, there is instead a circular unity of awareness and experience.

The importance of this experience not only to Whitman the mystic but also to Whitman the democratic reformer can hardly be exaggerated. In the same essay, Democratic Vistas, he writes:

... in respect to the absolute soul, there is in the possession of such by each single individual, something so transcendent, so incapable of gradations (like life), that, to that extent it places all beings on a common level, utterly regardless of the distinctions of intellect, virtue, station, or any height or lowliness whatsoever. . . $(P W, 2: 380)$

In particular, I would call attention to Whitman's claim that this direct experience of pure consciousness (or "soul" or "Self") "places all beings on a common level." Whitman the social reformer has, then, discovered 
through mystical experiences a natural basis for human equalityamong the sexes and within each sex, as among and within all races and nations. Despite all the human differences which comprise individuality and which inevitably lead to "gradation," yet there is something real and tangible which is shared universally (at least potentially) and indicates equality, the basis of democracy.

"Dyspeptic amours" are antipathetic to the democratic experience of pure consciousness, as is sexual repression. Both destroy the integrity of the whole by focusing on body parts. Whether one focuses with desire or repugnance makes little difference. Rather than affirming her body as a joyous whole, the "decent" woman swaddles her fragmented anatomy, especially the offensive parts, and separates out a category of normal urges and functions as shameful, with which category she then becomes inordinately preoccupied. A few superficial changes-flaunting what the "decent" woman swaddles - and we have the whore. Whether women are cast down or placed on a pedestal-whores or ladies-either way they are denied democratic equality and kept at arm's length.

In subtler ways as well Whitman's mystical experiences colored his view of male-female relations. The experience of pure consciousness, for example, is characterized by wholeness. We find this quality at the opening of "Song of Myself" in Whitman's heightened awareness of the completeness of his physiology, "My respiration and inspiration, the beating of my heart, the passing of blood and air through my lungs ..." $(L G, 29)$, and then, surprisingly, of the larger whole created by the linkage of Whitman's "internal reality," let us say, his physiology, with the "external reality," the natural world around him, via his alert senses. Later in the poem this process is enacted again, in Section 24, as Whitman begins to catalog parts of his anatomy and quickly becomes increasingly incorporative, describing his body topographically, as if it were in fact both itself and the whole scene around it as well:

Root of washed sweet-flag! timorous pond-snipe! nest of guarded duplicate eggs! it shall be you!

Mix'd tussled hay of head, beard, brawn, it shall be you!

Sun so generous it shall be you!

Vapors lighting and shading my face it shall be you!

You sweaty brooks and dews it shall be you!

Winds whose soft-tickling genitals rub against me it shall be you!

Broad muscular fields, branches of live oak, loving lounger in my winding paths, it shall be you! $(L G, 53)$

In the first two lines we can follow the correspondences easily: his hair is hay, his testicles duplicate eggs. But thereafter the elements of his body and of the surroundings become so fully identified that soon we cannot discern which are being described in terms of the otherwhether his body with nature or vice versa-and we can no longer tell 
precisely what part of his body he is describing or, indeed, whether he is describing an "internal" or "external" reality. In the 1855 "Preface" Whitman had philosophically asserted what he here enacts, that the poet "incarnates [his country's] geography and natural life and rivers and lakes." In the linear model of consciousness, separation or distinction is not only possible but inevitable. Passages such as the above are confusing, even unintelligible, because in Whitman's expanded state of awareness separation (which we assume) is disallowed: fusion, wholeness, unity prevail because of the self-referential, circular structure of the state of consciousness itself.

Even to describe the relation of his body with his surroundings as "linkage" is misleading in its linearity, for his senses seem more to encircle (notice the word "embraces," below) than merely to connect, and in encompassing thereby to internalize the larger whole:

The sniff of green leaves and of dry leaves, and of the shore and dark color'd sea rocks, and of hay in the barn,

The sound of the belch'd words of my voice loos'd to the eddies of the wind,

A few light kisses, a few embraces, a reaching around of arms,

The play of shine and shade on the trees as the supple boughs wag,

The delight alone or in the rush of the streets, or along the fields and the hill-sides, The feeling of health, the full-noon trill, the song of me rising from bed and meeting the sun. $(L G, 30)$

Whitman is rising and the sun is rising, two events which by their juxtaposition and implied equality of largeness and splendor seem more nearly one event (the two "meet"), contained and unified by the wholeness of Whitman's awareness. In "A Song of the Rolling Earth" Whitman proposes a philosophic rationale for this phenomenon of wholeness of awareness containing wholeness of reality:

I swear the earth shall surely be complete to him or her who shall be complete, The earth remains jagged and broken only to him or her who remains jagged and broken. $(L G, 223)$

Who remains jagged and broken? Certainly all who are "merely amative"-dyspeptic dandies to whom women are collections of body parts (what hair, what eyes, and so on). In Whitman's mystical experiences, all objects are known in terms of the self, or Self. In this state of expanded awareness, consciousness is circular, not linear: the object of awareness known in terms of the Self.

The conventional dandy, rather than seeing and appreciating women in terms of the Self, is locked into linear, objective consciousness in which women are distinctly and necessarily "other." So long as women are regarded in this objective way, the linear mode of consciousness hardens to a permanent inflexibility affecting all relations. Thus, as 
Whitman predicted in his 1856 letter to Emerson, "Of women just as much as men, it is the interest that there should not be infidelism about sex, but perfect faith. Women in these states approach the day of that organic equality with men, without which, I see, men cannot have organic equality among themselves" ( $L G, 737$; italics mine).

A few years after that letter, in 1860, Whitman and Emerson took their well-known walk along Boston common. Emerson urged Whitman to alter the sexual passages of Leaves, especially to delete "To a Common Prostitute." Whitman refused, or as he put it later, he "only answer'd Emerson's vehement arguments with silence" ( $P W, 2: 494)$. Whitman's equanimous silence was characteristic, even when confronting the disappointing or ugly in life. But in this case it may also have betokened repugnance at Emerson's capitulation to convention despite his knowing better. In addition to Emerson's stirring call for defiance of mere convention in "Self-Reliance," for instance, Emerson himself had had brief experiences of transcendental consciousness, a fact which provided an exclusive common ground between the two and enabled Emerson to read Whitman with special insight. ${ }^{9}$

For Whitman, in "To a Common Prostitute," is not speaking as an ego-bound "dandy" who sees the prostitute as separate from himself, an object of consciousness. Rather, he is speaking, as he often does, from that transcendent, unified level of consciousness in which the prostitute is known in terms of the unbounded Self. For this reason, he immediately identifies himself in the all-inclusive terms of "Nature." The sun does not exclude her, the waters do not refuse to glisten for her, therefore neither will he, the poet who accepts the entire cosmos as his extended anatomy, exclude or refuse her. The second section moves the poem away from what might otherwise be condescension. When Whitman says that he appoints her with "an appointment," he is surely not arranging a sexual liaison, as Emerson must have known. In newspaper editorials and articles Whitman had denounced prostitution as a threat to the family and as a pollutant of bloodlines, a fact that makes his compassion for this young woman all the more poignant. Whitman was, in his appointment, expressing instead his belief in the certainty of her own evolution to the same exalted level of awareness Whitman himself experienced. The "I" of "be patient and perfect till I come" is the cosmic "I" of transcendental consciousness, the blissful Self she will one day inevitably discover. Until she finds that Self on her own, Whitman salutes her "with a significant look that you do not forget me" ( $L G$, 387).

Whitman writes relatively little specifically about male-female relations, so "To a Common Prostitute" is particularly significant in that it exemplifies a male-female relationship at least approaching an ideal. The woman here, on the bottom rung of the social ladder, is recognized as an 
equal in a deep sense. She is not pruriently regarded as walking body parts, nor is she repulsive. She is not some "thing" to yearn for, with a longing born of dyspepsia, or prudishly to reject. She is whole within the wholeness of Whitman's awareness: the "object" known in terms of the subject, the knower. And her own awareness is itself developing toward that same ecstatic wholeness. Such is the indecent poem Emerson, even as he probably knew better, urged be dropped. Such is the poem Whitman defended with silence.

II.

Although Whitman generally used the phrenological term "adhesiveness" exclusively for male-male relations, I will try to show that a fuller understanding of the term requires that we transcend its phrenological boundaries (as with "amativeness"), and even its male-male limits. ${ }^{10}$ Again, Whitman's roles of reformer and mystic inform his idiosyncratic use of the term. The two roles can be described separately, but of course they are not completely distinct. They constantly interpenetrate, blend and almost merge. Having gained a transforming level of consciousness, the question then became, to Whitman the reformer, how to bring his revealed knowledge to bear upon, and similarly to transform, society at large?

The question was not merely speculative and abstract. To Whitman it was urgent and heartfelt. We must keep in mind that the hymns to adhesiveness, the "Calamus" poems, were written and revised as the nation tottered on the edge of, and then plunged into, the abyss of fratricidal war whose unspeakable horrors Whitman viewed from the depths: from the field hospitals that were little more than centers for inept amputation, often performed by furriers (who had the tools) impressed into service. Fear and hatred born of perceived difference, of separation, make men enemies and drive them to war. What could hold them together in peace?

Again, in Democratic Vistas:

Intense and loving comradeship, the personal and passionate attachment of man to man-which, hard to define, underlies the lessons and ideals of the profound saviours of every land and age, and which seems to promise, when thoroughly develop'd, cultivated and recognized in manners and literature, the most substantial hope and safety of the future of these United States, will then be fully express'd. ( $P W, 2: 414)$

For this reason, Whitman formulated plans to begin a program to train boys in the healthful development of perfect physiques. In 1849 he signed a note to pay twenty-five dollars in rent for a store in Granada Hall, in which to deliver a series of lectures on health and hygiene. Later he changed these plans to a series of articles instead, and still later 
to a book, which he never wrote. Further, he took a keen interest in hydropathy, in folk-remedies, and in various pseudosciences for their potential to enhance perfect bodies. ${ }^{11}$ The intention, I would suggest, was to cultivate in boys a psychophysiology of adhesiveness that would, in a wide-reaching application, prevent war, just as it would cure the dyspepsia of dandyism.

Whitman's blissful experiences of transcendental consciousness carried along with them a bodily ecstasy in which the most ordinary functions - talking, moving his head, walking-were surpassingly delightful. If we remember that to Whitman the body was soul, was, we might say, simply another expression of consciousness (as in Section 13 of "Starting from Paumanok," "Was somebody asking to see the soul?/ See your own shape and countenance ..."), his program for boys makes sense as a practical method to strengthen adhesiveness in society. Even in Vedic literature there are essentially two ways (although they are meant to be used in conjunction) to cultivate the bliss of the fourth state of consciousness: the mental approach of meditation, and the physical approach (called hatha yoga) consisting mainly of exercises (asanas) and breath control (pranayama). The mental bliss and the physical exhilaration of transcendence are simply two manifestations of a single phenomenon, since, in the Vedic cosmology as well as in Whitman's, mind and body are ultimately identical.

In terms of instructing others, Whitman understood the physical aspect better than the mental. In his own experience, he simply "invited" his soul. Often his soul, like a lover, accepted and filled him, overflowed him, with bliss. Merely to instruct boys, however, to "invite their souls" would, by the abstractness of that direction, probably be ineffective. But perhaps if he could train them to develop perfect physiques, then, since body and soul are so closely linked, or even identical, the mental counterpart-blissful, transcendental awareness of unity-would come along automatically. Evidence of such thinking can be found in notebooks as well as in Democratic Vistas:

A fitly born and bred race, growing up in right conditions of outdoor as much as indoor harmony, activity and development, would probably, from and in those conditions, find it enough merely to live-and would, in their relations to the sky, air, water, trees, etc., and to the countless common shows, and in the fact of life itself, discover and achieve happiness - with Being suffused night and day by wholesome extasy, surpassing all the pleasures that wealth, amusement, and even gratified intellect, erudition, or the sense of art, can give. ( $P W, 2: 416)$

Whitman changed but did not abandon his plans to instruct young men. "Calamus" may be read as a form of such instruction. Further, and we find this too in Democratic Vistas, he decided that "the ulterior object of 
political and all other government" is to "develop, to open up to cultivation, to encourage the possibilities of all beneficent and manly outcroppage ..." (PW, 2:379).

Because health in its root sense, "wholeness," was crucial to maintaining the state of consciousness on which the reality of adhesiveness depends, Whitman was vehement in his denunciations of prudery and of promiscuity, both of which fracture a holistic sense of body. What no doubt strengthened his feeling of kinship with Abby Price and other feminists was the shared belief that relations between the sexes were in need of radical alteration.

In a way, "To a Common Prostitute" is an example of adhesive love-or perhaps we should say, more precisely, the same kind of love that underlies manly love-applied here to a female relationship. ${ }^{12}$ If such general application seems to violate the specificity of the phrenological term, we must bear in mind that with even wider application Whitman envisioned this same principle of adhesiveness binding the States into a perfect union-and with still wider application, uniting the entire globe:

Lately I have wonder'd whether the last meaning of this cluster of thirty-eight States is not only practical fraternity among themselves - the only real union . . .-but for fraternity over the whole globe-that dazzling, pensive dream of ages! Indeed the peculiar glory of our lands, I have come to see is . . . more and more in a vaster, saner, more surrounding Comradeship, uniting closer and closer not only the American States, but all nations, and all humanity. . . . That, $\mathrm{O}$ poets! is not that a theme worth chanting, striving for? Why not fix your verses henceforth to the gauge of the round globe? the whole race? Perhaps the most illustrious culmination of the modern may thus prove to be a signal growth of joyous, more exalted bards of adhesiveness. . . . (PW, 2:484)

\section{Or, in "For You O Democracy:"}

I will make inseparable cities with their arms about each other's necks,

By the love of comrades,

By the manly love of comrades. $(L G, 117)$

Certainly the fullest expression of adhesive love in Whitman's work is found in male-male relationships. In his introduction to the correspondence, Edwin H. Miller calls attention, in a sentence heavy with innuendo, to Whitman's "attraction to semi-literate young men." Yet Miller is quite right that Whitman was so attracted, and indeed believed that only among such men did adhesive love thrive best. In a short prose piece called "Friendship, the Real Article," Whitman criticizes Bonaparte's inability to love, and then writes, "I am not sure but the same analogy is to be applied, in cases, often seen, where, with an extra development of the intellectual faculties, there is a mark'd absence of 
the spiritual, affectional, and sometimes, though more rarely, the highest aesthetic and moral elements of cognition" (PW, 2:532; italics mine).

The model of consciousness I offered earlier similarly suggests that "intellectuality" tends to strengthen linear, fragmented consciousness for two main reasons. One of the main functions of the intellect is to discriminate, to discern this from that-in other words, to fragment. The circular, transcendent model of consciousness, on the other hand, functions by incorporation, by synthesis. Also, intellectuality as defined by modern scientific methodology prides itself on separation of the knower from the known, with almost exclusive attention to the object of awareness. The knower, the observer, is dispassionate, unaffected, uninvolved, as nearly a cipher as possible. (Only recently have quantum physicists begun to consider subjectivity relevant to observed phenomena.) Throughout his work, Whitman counters the pitfalls of intellectuality, and the attendant danger of losing his self-referential mode of consciousness, by cultivating qualities of innocence, wonder and joy that may be said to comprise an internalized "child." 13 In "When I Heard the Learn'd Astronomer," for example, Whitman answers the astronomer's deadly erudition not with argument, but with the silence of childlike wonder: “. . . rising and gliding out I wander'd off by myself, / In the mystical moist night-air, and from time to time, / Look'd up in perfect silence at the stars." We recall, also, that it is a child who goes forth every day and experiences a unity of self and environment.

The child is central to Whitman's adhesive ideal. "Manly love," examined from the perspective of contemporary adulthood, is puzzling. The emotional attachment seems too intense for ordinary male-male friendships as we understand them. Bucke (or Bucke-Whitman) anticipated the problem, and (again from Walt Whitman's Autograph Revision of the Analysis of Leaves of Grass), wrote of Whitman: "Elsewhere he speaks of the sick, sick dread of unreturned friendship, of the comrade's kiss, the arm round the neck-but he speaks to sticks and stones: the emotion does not exist in us, and the language of his evangel-poem appears simply disgusting" (167). Indeed, embracing, kissing and handholding leave little doubt, for many readers, that Whitman's adhesiveness is at least homoerotic, or even homosexual.

Yet Bucke insisted of adhesive love that " 'Calamus' presents to us an equally advanced moral state in another direction - an exalted friendship, a love into which sex does not enter as an element" (166). ${ }^{14}$ It is not my intention here to grapple with the difficult question of Whitman's personal sexuality, but rather to understand the public ideal of adhesiveness Whitman presented in his writing. Because Whitman in- 
sisted in print that adhesiveness is non-sexual, let us see whether the poems of adhesiveness can sensibly be read without the element of sex, and what such a reading discloses.

In this regard, the problem of sexuality diminishes immediately if we consider adhesive love from the perspective of Whitman's "child within." In childhood, same-sex attachments can be very close. In the nineteenth century, when childhood itself may have been more distinct as a developmental stage than it is now, same-sex friendships might consequently have been even stronger. To express such affection by holding hands, or wrapping an arm around a shoulder, is, for children, quite natural and spontaneous. Only if we understand the internalized child Whitman deliberately and protectively cultivated does his "Calamus" poem "We Two Boys Together Clinging" make much sense at all-a poem he wrote at the age of forty-one, well past boyhood. The two, however, are boys within, clinging not only to each other, but together clinging to (and refusing to outgrow) the exuberance and inexhaustable energy (the poem is a concatenation of present participles) of boyhood itself. Fantasized and nostalgic, the poetic celebration of their boyish comraderie is rendered as a tribute to Tom Sawyerish bravado: the anarchic two sail, soldier and thieve together, "alarming priests" as they fulfill their "foray."

Whitman's Calamus letters to Peter Doyle, the most well-known of his semi-literate young men, and Whitman's closest approach to his ideal adhesive comrade, bear this quality of boyishness. Doyle does not understand Whitman's poems, which is fine with Walt-one senses it is preferred. They write instead about mutual friends, about baseball games, the weather, railroad wrecks, favorite places, and plans to get together for customary long walks and long suppers. ${ }^{15}$ If the content of these non-literary letters at times seems trivial, it is because Whitman, like a boy thinking of his friend, values most the company itself, the remembered and anticipated "forays," rather than conversation. Indeed, the "Calamus" poems themselves are not concerned with spoken sentiments. They are poems of doing, and poems of silence. Almost never do these comrades speak, but prefer, as in "Of the Terrible Doubt of Appearances," "the subtle air, the impalpable, the sense that words and reason hold not. . ." $(L G, 120)$. "A Glimpse," for instance, recalls meetings with Pete in a bar-room after he finished work. It concludes: A long while amid the noises of coming and going, of drinking and oath and smutty
jest,

There we two, content, happy in being together, speaking little, perhaps not a word.

$(L G, 132)$

If we try the non-sexual reading Whitman and Bucke solicit, we must keep bringing to these poems of adhesive love sensitivity to simple 
spontaneous affection of the sort we typically associate with a child. If we read "When I Heard at the Close of Day," for example, in a context of nineteenth-century boyish affection, we confront a startling image, more stunning to the contemporary reader for its baffling of expectations than it could ever be shocking by exceeding the expected: two grown men lie together like children: "In the stillness in the autumn moonbeams his face was inclined toward me, / And his arm lay lightly around my breast - and that night I was happy" $(L G, 123)$.

In the end, however, Whitman's adhesive ideal was only partly realized. Emerson, O'Connor and others disappointed, as did the man who was Whitman's fondest comrade, Peter Doyle. Problems were perhaps inevitable. From the first Whitman faced a conflict caused by deep tendencies in opposite directions, like shifting geologic plates: on the one hand he prized self-reliance, wholeness, "that which contains itself, which never invites and never refuses" $(L G, 223)$, as he put it in "A Song of the Rolling Earth." At the same time, as we know from the poignant "I Saw in Louisiana a Live Oak Growing," he could not live without a friend near.

At times in his letters to Doyle, we see Whitman's affection drifting toward the kind of doting he characterized as "amative" and found so repugnant in male-female relations. In one letter, for instance, dated December 12, 1873, he tells Doyle that he, Whitman, has had some light blue shirts made for Doyle as a gift. He is careful to specify that these are overshirts, to be worn over another shirt, and that he feels they will look best over white. Further, he urges Doyle to wear this combination with a black silk handkerchief tied around his neck, as he has seen on other workmen, and expresses eagerness to see him attired this way. Earlier, in 1870, after Doyle had failed to visit or even to write, in an anguished note Whitman had exhorted himself to "Depress the adhesive nature/ It is in excess-making life a torment / All this diseased, feverish, disproportionate adhesiveness." On July 30, 1870, Whitman answered a letter from Doyle, in part: "I never dreamed that you made so much of having me with you, nor that you could feel so downcast at losing me. I foolishly thought it was all on the other side. But all I will say further on the subject is, I now see clearly, that was all wrong." 16 In these two utterances from the same year, three years before he would send his gift of shirts, we glimpse the emotional roller-coaster Whitman was riding.

Whitman may have been himself aware that in his relationship with Doyle, and perhaps with others as well, adhesiveness was collapsing into something as repugnant to him as amativeness. Just as he had an idea of "mere amativeness," so he formed a category of "petty adhesiveness." "Perhaps" Whitman speculates, "the most illustrious culmination of the modern may thus prove to be a signal growth of joyous, more exalted 
bards of adhesiveness, identically one in soul, but contributed by every nation, each after its distinctive kind" ( $P W, 2: 484)$. Here we find expressed again the global scale of adhesiveness and the mystical sense that adhesiveness derives from the identity of "soul" underlying all manifest diversity. Significantly, though, he adds, a few sentences later, "I have thought that both in patriotism and song (even amid their grandest shows past) we have adhered too long to petty limits, and that the time has come to enfold the world." "Petty limits" here may belie, in its desire to shift the scale to the global, a subtle rejection of the individual, personal level of adhesiveness. Emotionally and psychologically, Whitman could more easily enfold the world than embrace an actual comrade, a Peter Doyle.

Just as the "lover" in Whitman's poetry is often not literally a person but the experience of transcendence in its ecstatic aspect (as in Section 5 of "Song of Myself," for instance, and repeatedly in the "Calamus" poems), so the same experience of transcendence is at times metaphorically "the comrade." 17 But Whitman's experience of blissful transcendence also diminished in frequency and in intensity in his last years. In "To the Sun-Set Breeze," one last time the comrade, the "companion better than talk" visits:

Ah, whispering, something again, unseen,

Where late this heated day thou enterest at my window, door,

Thou, laving, tempering all, cool-freshing, gently vitalizing. . . . (LG, 546)

But now there are no ecstasies, no forays. The companion comes now to nurse: the slowly dying poet's aching head and hands are soothed, his "weak-down, melted-worn" sweated body is blessedly cooled. As if recognizing a beloved face dimly seen, Whitman remembers that this within him now - "occult medicines penetrating me from head to foot"-this is the source of cosmic adhesiveness, the unifying spirit of all Nature, of himself and of the world: ". . . somehow I feel the globe itself swift-swimming in space." The last wryly triumphant line is, "Can I not know, identify thee?"

\section{Elizabethtown College}

\section{NOTES}

1 In a 1959 edition of Leaves of Grass edited by James E. Miller, Jr. (Boston: Houghton Mifflin), Miller includes a "Glossary of Difficult Terms" which succinctly illustrates Whitman's idiosyncratic usage. Some examples: "ambulanza," the Italian for field hospital, became for Whitman the term for an army ambulance. "Accouche," the French for "to be delivered of a child" became, for Whitman, a term meaning "to produce or to create." The word "jet," which can be used in general ways both as noun 
and verb, for Whitman specifically meant the male orgasm. "Imperturbe," "luminè," "presidentiad," "savantism" are a few of Whitman's many coinages.

A philosophical rationale for Whitman's linguistic unorthodoxy is reported by Traubel in his foreword to An American Primer (Duluth, MN: Holy Cow! Press, 1987), Whitman's discourse on language. He quotes Whitman: "I sometimes think the Leaves is only a language experiment - that it is an attempt to give the spirit, the body, the man, new words, new potentialities of speech-an American, a cosmopolitan . . . range of self-expression. The new world, the new times, the new peoples, the new vista, need a tongue according-yes, what is more, will have such a tongue-will not be satisfied until it is evolved."

2 Whitman's interest in phrenology has been widely discussed. The most thorough early study, focusing on Whitman's July 16, 1849 Fowler and Wells reading, is Edward Hungerford's "Walt Whitman and His Chart of Bumps," American Literature 2 (1931), 350-385. In a more recent work, Harold Aspiz (Walt Whitman and the Body Beautiful [Urbana: University of Illinois Press, 1980], 109-133) also offers a close analysis of the significance of phrenology for Whitman: both what he may have understood it to mean and what he made it mean in the creation of his public persona.

3 Floyd Stovall, Prose Works 1892 (New York: New York University Press, 1963-1964), 2:408. Further references abbreviated $P W$.

4 Harold W. Blodgett and Sculley Bradley, eds., Leaves of Grass, Comprehensive Reader's Edition (New York: New York University Press, 1965), 737. Further references abbreviated $L G$.

5 Jerome Loving, Walt Whitman's Champion (College Station: Texas A\&M University Press, 1978), 191. Further references abbreviated Champion.

6 Walt Whitman, Walt Whitman's Autograph Revision of the Analysis of Leaves of Grass, ed. Quentin Anerson (New York: New York University Press, 1974), 165.

7 Also in Democratic Vistas is the following description of "interior consciousness" or "soul":

I should say, indeed, that only in the perfect uncontamination and solitariness of individuality may the spirituality of religion positively come forth at all. Only here, and on such terms, the meditation, the devout ecstacy, the soaring flight. Only here, communion with the mysteries, the eternal problems, whence? whither? Alone, and identity, and the mood-and the soul emerges, and all statements, churches, sermons, melt away like vapors. Alone, and silent thought and awe, and aspiration-and then the interior consciousness, like a hitherto unseen inscription, in magic ink, beams out its wondrous lines to the sense. Bibles may convey, and priests expound, but it is exclusively for the noiseless operation of one's isolated Self, to enter the pure ether of veneration, reach the divine levels, and commune with the unutterable.

8 In an earlier article, "Figures of Transcendence in Whitman's Poetry," Walt Whitman Quarterly Review 5 (Summer 1987), 1-11, I offered a more fully elaborated description of transcendental consciousness, including specific connections with Vedic literature.

9 Near the opening of "Nature," for example, Emerson writes:

In the woods, we return to reason and faith. There I feel that nothing can befall me in life, - no calamity (leaving me my eyes), which nature cannot repair. Standing on the bare ground,-my head bathed in the blithe air and uplifted into infinite space,-all mean egotism vanishes. I become a transparent eyeball; I am nothing; I 
see all; the currents of Universal Being circulate through me; I am part or parcel of God.

The much derided image of a "transparent eyeball" is actually quite apt in suggesting an awareness which is unlocalized and expansive. See William H. Gilman, ed., Selected Writings of Ralph Waldo Emerson (New York: New American Library, 1965), 189.

10 In recent years "adhesiveness" has been examined as a key to Whitman's sexuality. Robert K. Martin in The Homosexual Tradition in American Poetry (Austin: University of Texas Press, 1979), 36ff., asserts that Whitman's use of the term "adhesiveness" has nothing to do with phrenology, but rather with Whitman's effort to develop an appropriate vocabulary of homosexual love as part of the creation of a homosexual identity. Michael Lynch in " "Here is Adhesiveness': From Friendship to Homosexuality," Victorian Studies 29 (Autumn 1985), 67-96, traces the development of phrenology from Europe to America and reaffirms the importance of phrenology, especially phrenological vocabulary, in creating a public homosexual identity.

11 For a discussion of Whitman's plans for boys and his interest in hydropathy, see Aspiz, 49-51.

12 Whitman's friendship with Mrs. Gilchrist is a better example of an actual female relationship approaching an ideal of adhesiveness. Mrs. Gilchrist has at times been portrayed as a somewhat silly woman pursuing a lost cause. She was, however, a deeply intelligent, extremely independent woman. If she did not find an ideal lover waiting for her when she crossed the Atlantic, she found instead a friend for life who fathomed and valued her gifts and her unswerving affection. For a reappraisal of their relationship, see Marion Walker Alcaro, "Walt Whitman and Mrs. G.,"Walt Whitman Quarterly Review 6 (Spring 1989), 153-171.

13 Whether or not there may have been influence from Emerson to Whitman, Emerson too uses the same image, and for a similar purpose: to infuse perception and intellection with the wonder that detached analysis destroys. "The Divinity School Address" is virtually structured around the child image, and in the midst of recurrent images of the child in "Self-Reliance," Emerson writes: "The nonchalance of boys . . . is the healthy attitude of human nature." Even preceding the mystical experience cited in note 8 above, Emerson says: "In the woods, too, a man casts off his years, as the snake his slough, and at what period soever in life is always a child."

14 Bucke and Whitman also include a lengthy quotation from an article entitled "Walt Whitman the Poet of Joy" by Standish O'Grady, published in Gentleman's Magazine (December 1875), which claims that Homerian male friendship was the fruition of an ideal which later degenerated: "The Greeks were well acquainted with that passion, a passion which in later days ran riot and assumed abnormal forms . . ." (166).

15 Whitman claimed they often walked as much as ten miles in one excursion, an appropriate pastime considering that the Fowler and Wells symbol of adhesiveness depicted two men strolling together.

16 Edwin H. Miller, ed., The Correspondence, vol. 2 (New York: New York University Press, 1961), 101.

17 Divinity itself is described so, as at the end of Section 45 of "Song of Myself": "The Lord will be there and wait till I come on perfect terms, / The great Camerado, the lover true for whom I pine will be there." 